\title{
AZ EURÓPAI MODELLEZÉSI ÉS SZIMULÁCIÓS TÁRSASÁG 33. NEMZETKÖZI KONFERENCIÁJA
}

\author{
2019. június 11-14., Caserta (Olaszország)
}

Németh András Olivér ${ }^{1}$

\section{ÖSSZEFOGLALÓ}

Az Európai Modellezési és Szimulációs Társaság (European Council for Modelling and Simulation, ECMS) 1986 óta évről évre megrendezi interdiszciplináris konferenciáját. A rendezvényt minden évben máshol tartják, a 2010-es Kuala Lumpur-i konferenciát leszámítva mindig Európában rendezték meg - két évvel ezelőtt például Budapesten, csakúgy, mint 1996-ban is. A 2019-es ECMSkonferencia helyszíne a több mint harmincezer diákot oktató Luigi Vanvitelli Egyetem volt a Nápolyhoz közeli Caserta impozáns királyi palotájának szomszédságában.

A konferencia valóban interdiszciplináris, hiszen az előadott hatvanhat tanulmányt nem a tudományterület, hanem a modellezésre, illetve szimulációra építő megközelítésmód köti össze. Természettudományi, műszaki, informatikai és társadalomtudományi témák egyaránt megjelentek a konferencia programjában, az előadott tanulmányok egy része alapkutatási jellegü eredményeket mutat be, de nagyon hangsúlyosak az alkalmazott kutatási eredmények, konkrét esettanulmányok is. A konferencia két plenáris előadója Alexander H. Lewis (George Mason Egyetem - USA) és Andrea Bobbio (Amedeo Avogadro Egyetem - Olaszország) volt. Itt érdemes megjegyezni, hogy a 2013-as konferencia nyitóelőadását például az a May-Britt Moser, norvég agykutató tartotta, akit egy évvel később orvostudományi Nobel-díjjal tüntettek ki.

Ebben a beszámolóban a Pénzügyi, közgazdasági és társadalomtudományi szekció tanulmányait foglaljuk össze. A szekcióban hagyományosan erős a magyar jelenlét, ez most még a szokásosnál is inkább így volt: egy orosz szerzőpáros két tanulmánya mellett a többi előadást a Budapesti Corvinus Egyetem oktatói és hallgatói tartották. Az előadások témakör szerint három fő csoportra oszthatók: demográfiai, makropénzügyi és mikrogazdasági kérdéseket vizsgáltak. A következőkben is e logika mentén ismertetjük a tanulmányok fő mondanivalóját.

1 Németh András Olivér egyetemi adjunktus a Budapesti Corvinus Egyetem, Gazdaságpolitika Tanszékén. 
Anna Bagirova és Oksana Shubat mindkét előadásukban a termékenység alakulását vizsgálták az oroszországi régiókban. A népesedési folyamatok társadalmi és gazdasági szempontból is relevánsak, a gyermekvállalást ösztönözni kívánó gazdaságpolitikai lépések Oroszországban is hangsúlyosak. A regionális vonatkozás pedig azért fontos, mert már egy Magyarországhoz hasonló méretű országban is jelentős területi különbségek lehetnek a gyermekvállalási hajlandóságban - természetes, hogy a lényegesen nagyobb országokban ez még erőteljesebben megfigyelhetö.

A szerzőpáros első előadásában („Dynamics Modeling and the Study of Birth Rate Determinants in Russian Regions") a teljes termékenységi ráta regionális alakulására koncentrált. A teljes termékenységi ráta (total fertility rate, TFR) azt mutatja meg, hogy a jelenlegi gyermekvállalási adatok alapján egy nő várhatóan hány gyermeket szül élete során. A termékenységi ráta az 1990-es években - jelentős részben a rendszerváltozást és a Szovjetunió széthullását követő gazdasági viszszaesés hatására - nagymértékben csökkent Oroszországban, majd 2000-2006 között, a meginduló gazdasági növekedéssel összhangban, érdemben emelkedett. A 2007 óta eltelt időszakban lassabb ütemben folytatódott a TFR emelkedése, annak ellenére, hogy a kormányzat igen jelentős támogatásokkal igyekszik növelni a gyermekvállalási kedvet. Az országon belüli regionális különbségek éppen ebből a szempontból is érdekesek lehetnek, hiszen ezek feltárása segítheti a jobban célzott kormányzati intézkedések kialakítását. Klaszterelemzés segítségével öt csoportba osztható a vizsgált 79 oroszországi régió. Az 1990-es évek tekintetében nincsenek jelentős különbségek: mind az öt klaszterben a TFR nagy visszaesése figyelhető meg. A klaszterek közötti különbségek a második és harmadik időszakban (2000-2006, illetve 2007 óta) rajzolódnak ki. Például a régiók egyik csoportjában 2007 óta alig emelkedik a termékenységi ráta, míg van olyan klaszter is, ahol kifejezetten gyorsult a TFR növekedése 2007-et követően. A szerzők a tanulmányban nem tértek ki arra, hogy kimutathatók-e olyan minták az egyes régiók társadalmi és gazdasági jellemzői tekintetében, amelyek együtt mozognak a termékenységi ráta szerinti klaszterképződéssel.

Második tanulmányuk („A Study of Regional Differentiation of the Fertility Resources Based on Convergence Models") azt a kérdést tette fel, hogy a 2000 és 2017 közötti időszakban megfigyelhető-e konvergencia az oroszországi régiók között az ún. reprodukciós képességhez kapcsolódó mutatók (terméketlenség aránya, 1000 szülőképes korú nőre jutó vetélések száma, 100 szülésre jutó vetélések száma) tekintetében. A szerzők vizsgálták a béta- és szigma-konvergenciát egyaránt. Egy mutatószám esetében akkor beszélhetünk a régiók közötti bétakonvergenciáról, ha minél alacsonyabb kezdetben a mutató értéke egy régióban, annál nagyobb ott a mutató változásának üteme a vizsgált időszak alatt. A szigma-konvergencia ezzel szemben az adott mutatóban jelentkező relatív szórás 
csökkenését jelenti. A két fogalom közötti viszony úgy fogalmazható meg, hogy a szigma-konvergenciából következik a béta-konvergencia, fordítva viszont nem ez a helyzet. A terméketlenség tekintetében a szigma-konvergenciát illetően nem egyértelmü a kép, míg enyhe béta-konvergencia kirajzolódik a régiók között. Ezzel szemben a vetélések számát tekintve a régiók közötti relatív szórás egyértelmüen növekvő tendenciát mutat a vizsgált időszakban. A konvergencia hiánya azt is jelenti, hogy a gyermekvállalást a reprodukciós képességen keresztül javítani kívánó, országos szintű intézkedések nem kellőképpen hatékonyak, a régiókra, régiócsoportokra összpontosító megközelítés sikeresebb lehet.

Kovács Erzsébet és Vaskövi Ágnes tanulmánya („Living Longer. Working Longer? - Life Expectancy and Retirement Age Trends in OECD Countries") a demográfia más területével foglalkozik: a várható élettartam, illetve a nyugdíjba vonulás átlagos idejének alakulását vizsgálja az OECD-országokban. A várható élettartam, illetve a nyugdíjas életszakasz átlagos hossza természetesen a nyugdíjrendszer, illetve egészségügy szempontjából is lényeges kérdés, így közvetlen költségvetési vonatkozásai is vannak. Az elmúlt évtizedekben a fejlett országokban folyamatosan emelkedett a születéskor várható élettartam (20 év alatt átlagosan 5 évvel a férfiak, 4 évvel a nők esetében). Ugyan ennél mérsékeltebb ütemben, de a 65 éves korban várható élettartam is növekedett. Az adatok azonban azt mutatják, hogy az effektív nyugdijkorhatár, vagyis a nyugdíjba vonulás átlagos ideje nem tartott lépést az élettartam meghosszabbodásával, a férfiaknál átlagosan 1,4 évvel, a nőknél átlagosan 1,8 évvel emelkedett.

A szerzők főkomponens-elemzés segítségével a 2015-ös, nemenkénti várhatóélettartam- és effektív nyugdíjkorhatár-adatokból generáltak egy-egy összetett változót, amelyek között nem mutatkozik korreláció, vagyis nem igaz általánosságban, hogy egy adott országot jellemző, magasabb várható élettartam hosszabb aktív életpályával is együtt jár. Az eredeti változók alapján klaszterelemzést is végeztek a szerzők, amely kimutatta, hogy a 35 vizsgált OECD-tagország négy csoportba osztható. 12 ország (például Izrael, Japán, Svédország) tartozik az első csoportba, ahol a várható élettartam és az effektív nyugdíjkorhatár is átlag feletti. A második csoport 13 országát hasonló demográfiai adatok jellemzik, de ez az első csoporthoz képest lényegesen alacsonyabb effektív nyugdíjkorhatárral párosul. Öt keletközép-európai ország tartozik a harmadik csoportba, ahol a várható élettartam és az aktív életszakasz hossza is rövidebb az átlagosnál, míg további öt országra (például USA, Mexikó, Törökország) az jellemző, hogy a relatíve alacsony várható élettartam meglehetősen magas effektív nyugdíjkorhatárral jár együtt. Az, hogy egy-egy ország melyik csoportba tartozik, azt is meghatározza, hogy mekkora kihívásokkal kell szembenéznie a nyugdíjrendszer fenntarthatósága, illetve az egyének pénzügyi helyzetének stabilitása tekintetében. 
A makropénzügyi témák közül elsőként Varga Erzsébet egy érdekes adópolitikai lehetőség hatásait elemezte („Decreasing Progressive Tax Rates with Basic Income: The Golden Mean?"): egy olyan progresszív jövedelemadó hatásait, amelyben a marginális adókulcsok nem növekednek, hanem csökkennek. Egy jövedelemadó akkor tekinthető progresszívnak, ha az adóalap növekedésével az átlagos adókulcs emelkedik. Ha az adórendszert kiegészítjük egy egyösszegű transzferrel (alapjövedelemmel, „negatív adóval”), akkor csökkenő határadókulcsok mellett is lehet progresszív adóztatásról beszélni. Ehhez az szükséges, hogy a sávhatár feletti marginális adókulcs magasabb legyen a sávhatárhoz tartozó (és a transzfer miatt az alacsonyabb jövedelemszintekhez tartozó határadókulcsnál lényegesen alacsonyabb) átlagos adókulcsnál. A jövedelemadóztatással kapcsolatos viták legtöbbször az egykulcsos (lineáris) és a „hagyományos” progresszív adó közötti választásról szólnak, azonban érdemes megvizsgálni azt is, hogy a másik két lehetőséghez képest milyen hatásai vannak a fentebb leírt, „szokatlan” progreszsziónak.

A szerző három, ugyanakkora adóbevételt eredményező jövedelemadó-rendszert hasonlított össze a jövedelmi egyenlőtlenségek és az adók által okozott holtteherveszteség tekintetében. Az egyik egy 15\%-os, lineáris adó. A második egy „hagyományos” progresszív adó, amelyben az alacsonyabb jövedelmekhez 25\%-os, a magasabb jövedelmekhez 45\%-os marginális adókulcs tartozik. A harmadikban pedig felcserélődnek a marginális adókulcsok: az alacsonyabb jövedelmekhez tartozik a 25\%, a magasabb jövedelmekhez a $45 \%$. A második és harmadik esetet természetesen jelentős összegű transzfer egészíti ki, amelynek a mértéke attól függ, hogy mekkora jövedelemszintnél húzzuk meg a sávhatárt. A társadalmi egyenlőtlenségek tekintetében azt láthatjuk, hogy a lineáris adóhoz képest a „szokatlan” progresszió is jelentősen csökkenti a nettó jövedelmekben mutatkozó különbségeket, még ha nem is annyira, mint a „hagyományos” progresszív adóztatás. Másrészt viszont a szerző eredményei szerint előbbi kisebb holtteherveszteséget okoz. Vagyis a csökkenő határadókulcsokkal és egyösszegü transzferrel megvalósított progresszív adó hatékonysági és méltányossági szempontból is a lineáris és a „hagyományos” progresszív adó között van, azaz egyfajta „arany középútnak” tekinthető.

Boros Eszter az eurózóna országainak árszínvonal-alakulását és annak hatásait vizsgálta („A Fair Solution or Pure Theory: Price Adjustment in the EMU”). A téma relevanciáját az adja, hogy egy monetáris unióban a tagállamokat érő aszimmetrikus sokkok esetében a negatívan érintett ország számára a versenyképességjavítást célzó árfolyam-leértékelés lehetősége nem áll rendelkezésre. Ehelyett csak az ún. belső leértékelés lehetséges, vagyis az árak és bérek (relatív) csökkentésével lehet javítani a külkereskedelmi pozíciókat, és azon keresztül élénkíteni a gazdaságot. Ez azonban csak akkor müködik, ha az árak és bérek kellőképpen rugalma- 
sak. A szerző az eurózóna 2010-2017 közötti adatait elemezte egyrészt a külkereskedelmi árszínvonal alakulása tekintetében, másrészt abból a szempontból, hogy az árak változása hatással volt-e a tagállamok versenyképességére. Az eurózóna egyes országcsoportjaiban alapvetően hasonló pályát követtek az export-, illetve importárak, a mediterrán országokban és Írországban azonban ezzel együtt is megfigyelhető a belső leértékelés jelensége. Egyrészt az exportárak kevésbé emelkedtek, illetve jobban csökkentek, mint az eurózóna más térségeiben, másrészt az importárak és hazai árszínvonal változásának különbsége is nagyobb volt, ami az import hazai termeléssel való helyettesítéséhez vezethet.

Másfelől az is kérdés, hogy a relatív árváltozások tényleg eredményezik-e a versenyképesség javulását. Ennek vizsgálatához az export változásának dekompozíciójára van szükség. A teljes exportváltozás ugyanis három részre bontható fel: a célországban növekszik az aggregált importkereslet, a célországban az átlagosnál nagyobb mértékben nő azon termékcsoportok iránti kereslet, amelyben a vizsgált ország jelentősebb piaci részesedéssel bír, illetve a vizsgált ország növeli piaci részesedését az egyes termékcsoportok esetében. A három hatás közül valójában csak a harmadik jelenti a tényleges versenyképesség-javulást. (Hasonló dekompozíció elvégezhető az import tekintetében is.) A szerző panelökonometriai eszközökkel vizsgálja a külkereskedelmi árszínvonal és a tényleges versenyképesség-változás közötti viszonyt. Az export tekintetében meglepő eredményekre jut, hiszen eredményei szerint csak a mediterrán országokban járt együtt az exportárak csökkenése tényleges versenyképesség-javulással, az eurózóna többi tagállama esetében inkább fordított a viszony. Az importhelyettesítés vonatkozásában már a várakozásoknak jobban megfelel az eredmény: az importáraknak a hazai árszínvonalhoz viszonyított relatív emelkedése valóban azzal járt, hogy a hazai termelők piaci részesedése növekedett.

Vidovics-Dancs Ágnes, Juhász Péter, Szücs Nóra és Hajnal Gábor tanulmányának („How to Improve Your Sovereign Rating? - A Case Study on Hungary”) középpontjában a Fitch szuverén adósságokra vonatkozó hitelminősítő modellje áll. A pénzügyi válság óta megfigyelhető a hitelminősítő intézetek transzparenciájának növekedése, amely folyamat részeként az intézetek rendszeresen nyilvánosságra hoznak módszertani dokumentációkat, modell-leírásokat. Ezek segítségével pedig többé-kevésbé pontosan rekonstruálhatóvá válnak az általuk alkalmazott modellek. A rekonstruált modellek természetesen ezzel együtt sem mindig adják vissza tökéletesen a valós adósbesorolásokat, részben azért, mert a tényleges modellekkel, illetve a felhasznált adatokkal kapcsolatban nem minden információ nyilvános, részben pedig azért, mert a hitelminősítő intézetek döntései - például nehezen számszerüsíthető folyamatok, jelenségek figyelembevétele miatt - kismértékben el is térhetnek az általuk alkalmazott modellek eredményeitől. 
Mindezzel együtt hasznos következtetések adódhatnak a rekonstruált modellek elemzéséből.

A szerzők a Fitch modelljének rekonstruálásával azt vizsgálták, hogy a fő makrováltozók (GDP, pénzmennyiség, infláció, bruttó államadósság, külső államadósság) változásai hogyan hatnak a szuverén adósbesorolásra. Parciális elemzést végeztek, vagyis arra koncentráltak, hogy hogyan alakul a minősítés, ha egy vagy két makroadatot sokk ér, miközben a többi változatlan marad. A BBBkategóriából indultak ki, hiszen ez volt Magyarország besorolása a cikk írásakor, így tulajdonképpen úgy is megfogalmazható a tanulmány kérdése, hogy a magyar adatoknak hogyan kell változniuk a hitelminősítés javulásához/romlásához. Az egydimenziós hatások tekintetében azt találták, hogy a felminősítéshez egy-egy változó irreális javulására lenne szükség, miközben a leminősítéshez már a változók realisztikusabb mértékű romlása is elvezethet. A kétdimenziós megközelítés eredményei szintén azt mutatják, hogy még két releváns makrováltozó egyidejü, reális mértékű változásai is nehezen eredményezik a hitelminősítés módosítását, főképpen javulását.

A pénzügyi szabályozások témakörét érintette Kádár Csaba előadása („Is the Effect of Current Rules of International Accounting and Prudential Tools Make the Bank Reserving Pro-Cyclical? - Modelling of Impairment under IFRS 9 and Countercyclical Capital Buffer"). Azt a kérdést járta körül, hogy milyen hatásai vannak az újabb, szigorúbb számviteli és pénzügyi szabályoknak, illetve a Bázel III által bevezetett kontraciklikus tőkepuffer-szabályozásnak. A szerző azt modellezte, hogy mennyiben kezeli másként a 2018-tól érvényben lévő IFRS 9 (International Financial and Reporting Standards) rendszer a hitelveszteség problémáját a korábbi számviteli rendszerhez képest. Eredményei azt mutatják, hogy az IFRS 9 számítási rendszere hamarabb és nagyobb mértékben képes figyelembe venni a hitelveszteség által okozott értékvesztést. Modelljét ezt követően kiegészítette a kontraciklikus tőkepufferre vonatkozó elöírással is, és arra az eredményre jutott, hogy az új számviteli és prudenciális elöírások bevezetése - minden más változatlansága mellett - összességében anticiklikus hatású.

Szintén a pénzügyi szektorhoz kapcsolódik Illés Ferenc, Muratov-Szabó Kira, Prepuk Andrea, Szodorai Melinda és Váradi Kata tanulmánya („Together Forever or Separated for Life: Stress Tests of Central Counterparties in Case of Merged and Separated Default Funds"), amelyben azt vizsgálták, hogy milyen előnyei és hátrányai vannak annak, ha egy két piachoz is kapcsolódó központi elszámolóház közös vagy külön-külön nemteljesítési alapot müködtet az egyes piacokon. Modelljükben négy klíringpartner szerepel, akik két pénzügyi termékkel (egy részvénnyel és egy devizával) kereskedhetnek az azonnali és a derivatív piacokon. Egyikük csak az azonnali piacon kereskedik a részvénnyel, a másik három mindkét piacon megjelenik. A pénzügyi termékek árfolyamai sztochasztikus fo- 
lyamatot követnek, illetve bizonyos valószínűséggel sokkok érik azokat. Ennek függvényében meghatározhatóak a különböző pénzügyi termékekkel kereskedő szereplők által fizetendő marzsok és a nemteljesítési alaphoz való hozzájárulásuk. A szerzők 101 szimulációt futtattak le a pénzügyi termékek árfolyamára vonatkozóan. A szimulációk eredménye szerint a mindkét piacon működő szereplők számára kedvezőbb az egyesített piac, mert ebben az esetben kisebb marzsokkal kell számolniuk, mint két alap esetében. A csak az azonnali piacon kereskedő szereplő számára viszont ez kedvezőtlenebb, mert a többiekhez viszonyítva megnő a relatív hozzájárulása a nemteljesítési alaphoz. A központi elszámolóháznak prudenciális szempontból jobb az elkülönített piacok rendszere (hiszen a nemteljesítési alapokhoz való nagyobb hozzájárulások nagyobb biztonságot jelentenek problémák esetére), azonban a nagyobb marzsok nehezítik számára az ügyfelek megtartását, vagyis a piaci versenyképesség szempontjából hátrányosak.

Két, a közgazdaságtan különböző területeiről származó eszköztárat kapcsol össze Fekete Márta, Németh András Olivér, Száz János és Vidovics-Dancs Ágnes cikke („Simulating Bankruptcy - The Effects of Bailouts”), amelyért a szerzők megkapták a konferencia legjobb tanulmányának járó díjat (Best Paper Award). Az egyik a Kornai János által bevezetett puha költségvetési korlát fogalma, amely szerint az állami vállalatok, intézmények kevésbé vannak hatékony gazdálkodásra ösztönözve, hiszen probléma esetén a kormányzat segítő kezet nyújt. Viszont a kimentésnek ez a lehetősége tulajdonképpen egy opcióként értelmezhető az intézmény számára, azzal a különbséggel, hogy nem maga az intézmény vásárolja és hívja le az opciót, hanem azt mintegy ajándékként kapja (vagy kilobbizza) a kormányzattól. Ezért merült fel a szerzőkben annak a lehetősége, hogy a trinomiális fáknak az opcióárazásban alkalmazott eszköztára alkalmazható lehet a kimentésekkel kapcsolatos kérdések statisztikai megközelítésű elemzésére is.

A felépített modell egy hipotetikus kórház likviditási helyzetére vonatkozik. Ez a likviditási helyzet bizonyos korlátok között véletlen bolyongást követ meghatározott átmenet-valószínüségekkel. A szükségesnél alacsonyabb likviditás esetén a kórház valamekkora valószínűséggel csődhelyzetbe kerül, hacsak - szintén meghatározott valószínüséggel - a kormányzat ki nem menti. A szerzők azt vizsgálták ebben a keretben, hogyan függ a csőd- és kimentési valószínűségektől a kórházak megmaradási esélye. A tanulmány további része azt a kérdést is felveti, hogy két vagy több kórház esetében mennyiben függ ez a megmaradási esély attól, hogy a kormányzat egyikükre összpontosítja kimentésre fordítható erőforrásait, vagy pedig megosztja azokat a kórházak között. A trinomiális modellre építő szimulációs eredmények szerint valamivel magasabb a kórházak csődbe jutásának valószínüsége az utóbbi esetben, azonban nem ez az elsődleges kérdés, hanem az, hogy a kórházak likviditási helyzete mennyire korrelál egymással. 
Végezetül Gelányi Ildikó, Juhász Péter és Száz János tanulmánya („Delivery Risk in a Supply Chain with a Dominating Member: Modeling the Effect of the Inventory Policy”) egy - az ellátási láncokra épülő mai gazdaságokban egyre fontosabbá váló - készletezési problémát modellez. A probléma jelentőségét az adja, hogy egy több vállalatból álló ellátási lánc versenyképessége jelentős mértékben függ a lánc tagjai közötti szállítások pontosságától. A szállítással kapcsolatos problémák kezelésére a tagok készleteket halmozhatnak fel, gondot okozhat azonban, hogy az egyes vállalatok számára optimális készletmennyiség nem feltétlenül optimális a teljes ellátási lánc számára. Amennyiben a láncnak van domináns tagja, akkor azonban ez a vállalat elérheti, hogy a többiek is a lánc egésze szempontjából optimális készletezési stratégiát kövessék.

Modelljükben három vállalatból álló ellátási lánc szerepel. A vállalatok közötti szállítások időpontjában van némi bizonytalanság, váratlan események késéseket vagy akár korábbi szállításokat okozhatnak. A vállalatok dönthetnek a megállapodás szerinti szállítási ciklusnak megfelelő inputkészlet mellett vagy az említett bizonytalanságok miatt egy nagyobb ellátásbiztonságot eredményező készletet is felhalmozhatnak. Ez utóbbi egyfelől természetesen többletköltséget jelent, azonban az ellátási lánc egésze szempontjából is növeli a termelés kiszámíthatóságát, hiszen csökkenti annak valószínüségét, hogy a lánc valamelyik pontján megakadjon a termelési folyamat az inputforrás időleges elapadása miatt. A szerzők azt vizsgálták szimulációk segítségével, hogy ha az ellátási láncnak van egy domináns (legnagyobb árbevétellel rendelkező) szereplője, akkor ez a vállalat hogyan tudja elérni, hogy a lánc többi tagja is a nagyobb készlet felhalmozását válassza. Konkrétabban: mekkora árrés esetén éri meg a vállalatoknak a nagyobb készlet. $\mathrm{Az}$ árrésre azért van hatása a domináns szereplőnek, mert a vállalatok egymás beszállítói, vagyis a közöttük kialakuló ár alku kérdése. A konkrét eredmények természetesen attól függnek, hogy az ellátási lánc melyik tagja a domináns szereplő, de az általánosságban megállapítható, hogy inkább a lánc első részén lévő vállalatokat kell nagyobb árréssel ösztönözni az óvatosabb készletezésre, a lánc végéhez közelebbi vállalatok számára már kis árrés esetén is ez az optimális.

A fentebbi rövid összefoglalók természetesen csak a tanulmányok leglényegesebb pontjait igyekeztek kiemelni a technikai részletek nélkül. Remélhetőleg ez is elegendő annak a bemutatására, hogy milyen sokszínű volt a 2019-es ECMSkonferencia közgazdasági szekciója mind az előadások témája, mind a választott módszertan szempontjából. 